一技術報文一

\title{
炭素緎維の熱リン酸中における耐食性評価
}

榎本 三男, 大橋 敏孝*, 畑 都美雄, 鈴木 義雄, 前田真理子 ${ }^{\dagger}$, 佐藤 穎生 ${ }^{\dagger}$

\section{Evaluation of Corrosion Resistance of Carbon Fibers in Hot Phosphoric Acid}

\author{
Mitsuo ENOMOTO, Toshitaka OHASHI*, Tomio HATA, Yoshio SUZUKI, \\ Mariko MAEDA ${ }^{\dagger}$ and Hidetaka $\mathrm{SATO}^{\dagger}$
}

Received March 8, 1996 ; Accepted January 22, 1997

\begin{abstract}
In order to improve the durability of Phosphoric Acid Fuel Cell (PAFC) substrates, relations between corrosion resistance and physical properties of several carbon fiber samples were examined. It was confirmed that the physical properties and the texture of each sample influenced to the corrosion behavior. PAN based carbon fiber showed surface of onion-skin structure, which was inert in hot phosphoric acid. In addition, high modulus carbon fibers that was high dgree of graphitization brought about only a little weight loss at $1.1 \mathrm{~V} / \mathrm{RHE}$ in phosphoric acid at $210^{\circ} \mathrm{C}$. The corrosion behavior of GC (glass like carbon) fiber was unique. The corrosion current for the GC fiber changed only slightly with the rise of potential(0.9-1.1V/RHE) compared with those for other samples.
\end{abstract}

\section{1 緒 言}

リン酸型燃料電池 (Phosphoric Acid Fuel Cell; 以下 P A F C と略記) 発電プラントの実用機を開発するため に, 電池本体の性能や寿命, 信頼性を確保し, プラント 全体のコンパクト化と低コスト化を図ることが最重要課 題である. そこで高出力化とともに一層の長寿命化・信 頼性向上を図るためには，電池本体を構成するカーボン 材料の耐食性向上が望まれている。しかし電池の構成要 素としてカーボン材料に必要な濑能は明らかなものの, カーボン材料の特性が電池の性能に与える影䇾について は一部の報告 ${ }^{1-4)}$ がなされているだけで，その基本的特 性之耐食性，熱伝導性など，さらにP A F Cの赛用上の 特性との関係を示した報告は少ない。

ところで, 電池反応が起きる電極触媒層に使用される カーボンブラック(触媒担体)については，黒銷化度を高

東海カーボン(株)富士研究所(テ410-14 静网県駿東郡 小山町須走394-1) Fuji Research Laboratory, Tokai Carbon Co., Ltd. (394-1, Subashiri Oyama-cho, Sunto -gun, Shizuoka-ken, 410-14 Japan)

†東京電力 (株)エネルギー・環境研究所(十230 横浜市鹤 見区江ヶ崎町4番1号) Energy and Environment R\&D Center, Tokyo Electric Power Company (4-1 Egasaki -cho, Tsurumi-ku, Yokohama, $230 \mathrm{~J}$ apan)

Key Words; PAFC substrate, Carbon Fiber, Corrosion, Degree of graphitization
めると腐食電流が小さくなり，耐食性が向上すること” が知られている. しかし，電極基板やセパレー夕用カー ボン材料に関する実用上の信頼性向上に関する報文は見 当たらない。

P A F Cの電栖基板は骨格となる炭素織維とバインダ 一樹脂の炭化物からなる複合組織を有しているので, 電 極基板として評価するには様々な要因が考えられる、こ れらのことから我々は，電極基板の骨格を形成している 炭素織維についてその基本的特性を明らかにし, 熱リン 酸中での耐食性との関係を調べた結果を報告する.

\section{1 試料}

\section{2 実 蝓}

炭素絨維には基本的特性, 構造の異なる様々な品種が あり，その物性，組織の違いは原料，製法によるところ が大きい. P A F C 電極基板の炭素織維は通常安価な沉 用グレードが使用されているが，本研究では炭素織維の 物性とその耐食性の関係を明らかにするため, Table 1 に示した高性能グレード, 沉用グレードから広笧囲の品 種の代表的な 6 種の市販の炭素織維を選定した. 高性能 グレードの炭素瀻維からはP A N系, 石油ピッチ系のそ れぞれ 2 品種を選定し，弾性率の異なる織維 $\mathrm{A} \sim \mathrm{D}$ を試 料とした，また，汎用グレードからは等方性構造の石炭 ピッチ系 (E) と, フェノール樹脂織維(炭素織維前駆体) を $2000^{\circ} \mathrm{C}$ で焼成したガラス状カーボン質の炭素絾維 (F) を試料とした。 
Table1 Carbon fiber samples used in the study.

\begin{tabular}{|c|c|c|c|c|c|c|}
\hline Name & Type & Precursor & Texture & $\begin{array}{l}\text { Density } \\
\left(\mathrm{g} / \mathrm{cm}^{3}\right)\end{array}$ & $\begin{array}{l}\text { Tensile } \\
\text { strength } \\
(\mathrm{MPa})\end{array}$ & $\begin{array}{l}\text { Young's } \\
\text { modulus } \\
(\mathrm{GPa})\end{array}$ \\
\hline A & HP Type & $P A N$ & Onion skin - random core & 1.76 & 2800 & 200 \\
\hline $\mathrm{B}$ & H P Type & PAN & Onion skin-random core & 1.93 & 3000 & 510 \\
\hline $\mathrm{C}$ & H P Type & Pitch & Radially folded & 2.14 & 5700 & 540 \\
\hline $\mathrm{D}$ & H P Type & Pitch & Radially folded & 2.18 & 3400 & 680 \\
\hline $\mathrm{E}$ & G P Type & Pitch & Randam(Isotropic) & 1.66 & 630 & 30 \\
\hline $\mathrm{F}$ & G P Type & Phenolic resin & Amorphous(Glass like carbon) & 1.34 & 400 & 27 \\
\hline
\end{tabular}

市販の炭素瀻維はサイジング刻(エポキシ樹脂系)が付 着しているので，炭素䌤維をアセトンでソックスレー抽 出器を用い除去した (一尽夜)後, 完全にサイジング風の

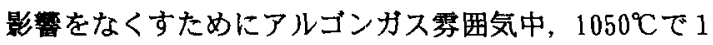
時間熱処理を行った.

\section{2 物理特性評価}

物理特性として密度, 機械的特性はTable 1 に示した 通りであるが, 耐食性と関連性の強いと思われる特性と して，表面および断面のS E M観察から炭素織維の楧造 的特徵，組織を調べ，さらに黒鈶化度，表面酸素量，不 純物量を評価し耐食性の結果と関連づけだ!。

黒鈶化度は，織維を粉砕し，学振法に準じて格子面間 隔 $\mathrm{d} 002$ ，結晶子の大きさLc (002) を測定し，黒鈷化の 進行度合いを評価した. また, 表面酸素量はXPＳによ る $\mathrm{O}_{1 \mathrm{~s}} / \mathrm{C}_{1 \mathrm{~s}}$ 比を测定，不純物は爽分，硫黄分，燐分， 窒素分，金属不純物11元素を測定した.

\section{3 耐食性評価}

Fig. 1 に示したように200〜210Cに保持された熱りン 酸中で, 以下の 2 つの腐食条件にて腐食試験を行って評 価した。

\section{(1) 定電位腐食試験}

温度 $200^{\circ} \mathrm{C}$ のン酸中で, ポテンシオスタットで $0.9 \mathrm{~V} /$ RHE, $1.0 \mathrm{~V} / \mathrm{RHE}, 1.1 \mathrm{~V} / \mathrm{RHE} の 3$ 水準の一定電位に制御, 720分後の電流を測定して, その電流值を炭素織維の腐 食反応電流とみて耐食性の良否を相対比較した，腐食電 流密度は, 電解液に浸漬していた試料部分を切り取って 重量を測定し，その重量に相当する表面積 $(\mathrm{Kr}$ 吸着表面

積)で電流值を制った値で表した。

(2) 定電位長時間腐食試驗

上記定電位腐食試験の最も高い電位で, 温度を $10^{\circ} \mathrm{C}$ 上 げた条件下で長時間腐食試験を行い, 腐食による重量変 化および形状の変化を捉え, 電流密度の比較と合わせて 耐食性を評価した、その腐食条件は，温度 $210^{\circ} \mathrm{C}$, 電位 1. 1V/RHE，時間10,000分である.
参照電極は銀・塩化銀電極 $(0.197 \mathrm{~V} / \mathrm{SHE})$ を用いた.

温度 $200 ， 210^{\circ} \mathrm{C}$ 保持されている電解液槽から液絡を 通して室温の $100 \%$ リ酸電解質と慗ぎ, 更に塩橋によ つて塩化カリウム飽和溶液と骜いだ。塩橋と室温 $100 \%$ リン酸の液間電位差は約 $0.004 \mathrm{~V}$ であり、実際の陽極電 位は前記表示より0.004V低くなっているが，ここでは 便宜上前に示した電位值を表記した。

電解液として使用したリン酸は不純物の影整をなくす ため高純度のリン酸 (閣東化学EL-UM85\%リン酸)を $200^{\circ} \mathrm{C}$ で窒素カスをバブリングしながら 4 時間以上保持, 脱水

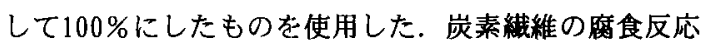
で水が消費されることが予想されたが，長時間腐食試験 においても腐食量は極微量で，かつ試料量に比べリン酸 は多量にあり腐食試験前後のリン酸濃度に変化がなかっ たことから，リン酸の水分調整は行わなかった．また， 電解液の濃度に変化がなかったこと, 電解液中での窑素 ガス導入は試料が流動状態になり不安定なことから，電 解液槽内の雾曲気は空気常圧下で行った。

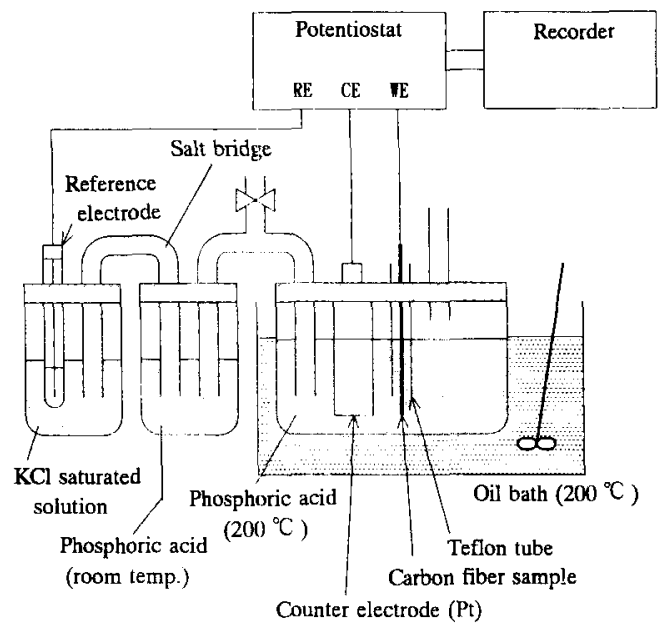

Fig.1 Schematic diagram of corrosion test apparatus. 
炭素織維 $\mathrm{E}$ 以外の腐食試験の試料は以下の方法で作製 した，長さ約 $150 \mathrm{~mm} に$ 切断したトウを90,000フィラメン ト(Fは40，000フィラメント)になるように束ね，その端 部にフェノール樹脂を塗布して，硬化後，サイジング剂 を除去した。これをアルゴンガス雾囲気中で $1050^{\circ} \mathrm{C}$ に熱 処理して，塗布したフエノール樹脂を炭化処理したもの

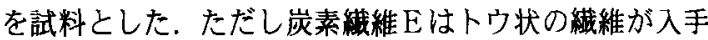
できなかったので, $100 \mathrm{~mm}$ チョップのものを入手し約 0.3 $\mathrm{g}$ 束ねて同様に樹脂を塗布しで試料を作製した。試料上 端部に塗布して炭化したバインダー部分は電解液に浸ら ずに炭素織維部分のみがリン酸電解液と接触している状 態にした．炭素織維試料のリン酸電解液に浸漬している 長さは，E以外の試料は65mとし，Eは $35 \mathrm{~mm}$ とした。こ の時に炭素縺維の毛管現象による電解液の上昇はほとん ぞ見られなかった。

\section{3 結果及び洘察}

\section{1 炭秦辐維の基本的特性}

\subsubsection{S E M写高から見られる炭秦辕䊒の特徽}

Fig. 2 に炭素織維の断面及び表面のS E M 観察写真を示 した。PAN系炭素織維A，Bの表面は，紡系時の収綟 によると思われる䝛が見られる．高強度品Aの断面は比 較的硬質な破面を示すのに対し，高弾性率品Bは黒鉿化 度が高く P A N系炭素緉維特有のフィブリル構造に基づ く微細な凹凸のある破面であった．

ピッチ系炭素絾維 C及びDは，断面観察からラジアル 構造が確認され，弾性率の高いDの方が黒鈶化が進んで いるためラジアル構造がより一層明確に現れていた。ま た，この炭素紻維の表面には織維方向に微細な筋状凹凹 が確認された。

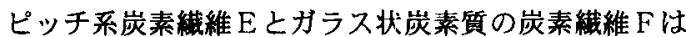
ともに無緊張下で焼成されているのでそれぞれ等方性構 造，アモルファスカーボン構造を有し，断面は硬質なガ ラス状破面を呈し，表面は非常に滑らかであった．

これら S E M観察から，原料，製法が異なる炭素織維 の構造的特徴を把握することができた。

\subsection{2 炭柔瓶維の黑鉛化度 6 種の炭素絾維試料の} 黒鈵化度をTable 2 に示した. Table 1 に示した炭素䋞維 の物理特性と関連づけると，高性能グレード炭素緎維 4 種 $(A \sim D)$ は織維方向に結晶配向があるため強度，弾性 率が高く，一般に言われているように弾性率の高い炭素 織維ほど黒鈶化度が高いことが碓認された，特に易黒鈶 化性のピッチを原料として緊張下で炭化されたと思われ るC，Dは，難黒鈶化原料を前䣕体とするP A N系炭素 䋐維よりも結晶子が発達している，また，結晶子が発達 し格子面間隔が小さい炭素織維洰よ゙密度は大きくなる傾 向がみられる。

無配向の汎用グレード炭素䋞維は黒鈗化度が低く， E

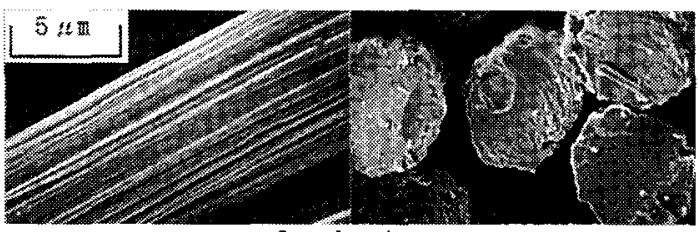

Sample A

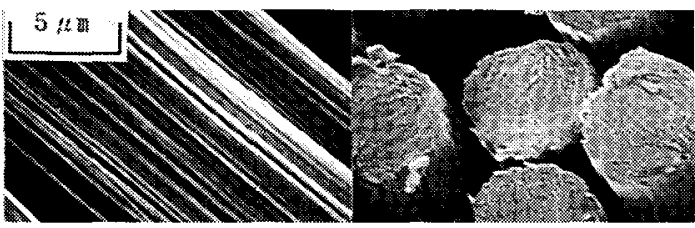

Sample B

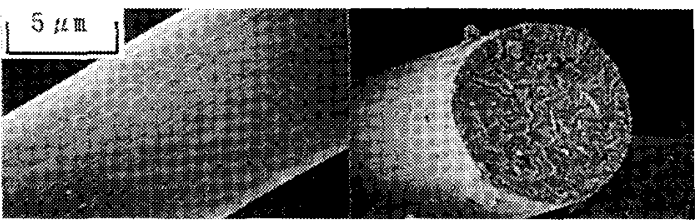

Sample C

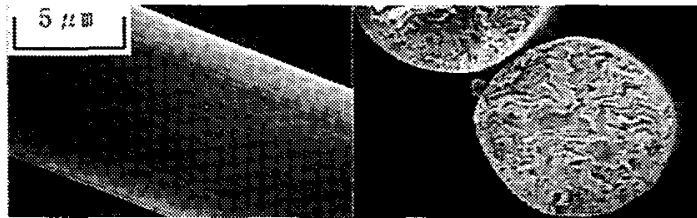

Sample D

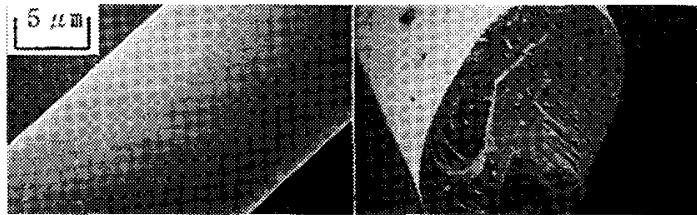

Sample E

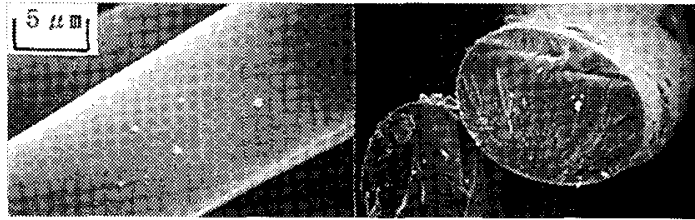

Sample F

Fig.2 SEM photographs of the typical microstructure of carbon fibers used in the study.

では炭素の(002) 回折線は確認されず，ほとんど黒鉿化 されていなかった。

3. 1.3 炭素找維の表面酸素各試料の表面性状の 指標の一つとなる表面酸素量を示す $\mathrm{O}_{1 \mathrm{~s}} / \mathrm{C}_{1 \mathrm{~s}}$ 比は0.02 〜0.06であって著しく小さかった，炭素織維表面は熱好 理クリーニングの效果により，含酸素表面官能基は極微 量とみられ，耐食性には影霫しないと思われる。 
Table2 Degree of graphitization and $0_{1 \mathrm{~s}} / \mathrm{C}_{1 \mathrm{~s}}$ ratio for samples.

\begin{tabular}{cccc}
\hline Sample & $\begin{array}{c}\mathrm{d} \text {-spacing } \\
\mathrm{d} 002 \\
(\AA)\end{array}$ & $\begin{array}{c}\text { Crystallite } \\
\text { size } \mathrm{Lc}(002) \\
(\AA)\end{array}$ & $\begin{array}{c}0_{1 \mathrm{~s}} / \mathrm{C}_{1 \mathrm{~s}} \\
\text { ratio }\end{array}$ \\
\hline $\mathrm{A}$ & 3.527 & 20 & 0.02 \\
$\mathrm{~B}$ & 3.424 & 77 & 0.02 \\
$\mathrm{C}$ & 3.437 & 129 & 0.03 \\
$\mathrm{D}$ & 3.401 & 210 & 0.02 \\
$\mathrm{E}$ & - & - & 0.05 \\
F & 3.556 & 20 & 0.06 \\
\hline
\end{tabular}

\subsection{4 岸秦轾稚に合有される不純物の確認不純物}

は酸化を促進あるいは抑制させる効果をもたらすことが あるので，熱リン酸中での耐食性を判断する上では重要 な因子である，試料の特徴的な不純物と金属不純物の全 量を知るため灰分量を测定し， Table 3 に示した。

試料 A， B及びFの死分量は他の試料と比較して多か った．試料Aはリンと窒素が多いのが特徴的で，リンが 灰分量を高くしていると思われ，これらの元素は前駆物 質から残留したものである，試料Aではこの残留した窒 素分が熱リン酸中での耐食性に悪影暨を及ほすことも考 えられるが，ここでは窒素含有の耐食性への影整までは 確認できなかった。試料B忙Aより高温で焼成されてい るためか，窒素，リンは少なかった。

試料 F は原料中に含まれていたと思われるカルシウム が多かったが, 後述する耐食性との結果から判断すると 炭素瀻維の黒鈶化度, 微細組織が大きく耐食性に反映し ているので,この程度の不純物量が耐食性に与える影譬 は小さかった.

また，Cは硫黄分が著しく多く，これも原料に由来す るものと思われるが，硫黄分は酸化を促進する効果はな い7ので，熱リン酸中での酸化腐食にも影暨を与えない と思われる．Cより高温焼成されている高弾性率炭素織 維Dでは硫黄分は砤量であった。

\section{2 炭泰織隻の熱リン酸中における㢦食性}

3. 2.1 定電位腐食試硂結果定常運転に近い電位で ある0.9V/RHEからやや高い電位である1.1V/RHEの 3 水準 の定㫣位において720分後の腐食電流密度の結果をFig. 3 に示した. 電流密度が高いことはリン酸電解頎中で活 性であることを示し，電流值が低い試料ほど耐食性が高 いことを示す。

0. $9 \mathrm{~V} / \mathrm{RHE} ゙$ は黒鈶化度の低い試料 Aが最も電流密度が 低く, 次いで B, C, F, Dの順で, 最も高い電流密度 を示したのは等方性構造のピッチ系汎用グレード炭素瀻
Table3 Impurity content in carbon fibers.

\begin{tabular}{ccrrrr}
\hline Sample & $\begin{array}{l}\text { Ash } \\
(\mathrm{ppm})\end{array}$ & $\begin{array}{c}\mathrm{P} \\
(\mathrm{ppm})\end{array}$ & $\begin{array}{c}\mathrm{S} \\
(\mathrm{ppm})\end{array}$ & $\begin{array}{l}\mathrm{Ca} \\
(\mathrm{ppm})\end{array}$ & $\begin{array}{c}\mathrm{N} \\
(\%)\end{array}$ \\
& & & & & \\
\hline $\mathrm{A}$ & 81 & 120 & 28 & 0.7 & 6.84 \\
$\mathrm{~B}$ & 47 & 9 & 46 & 1.1 & $<0.01$ \\
$\mathrm{C}$ & 10 & 1 & 3400 & 0.6 & $<0.01$ \\
$\mathrm{D}$ & 16 & 2 & 59 & 1.2 & $<0.01$ \\
$\mathrm{E}$ & 15 & 4 & 110 & 0.2 & 0.70 \\
$\mathrm{~F}$ & 65 & 7 & 48 & 20 & 0.01
\end{tabular}

維の試料 Eであった。1.0V/RHE，1.1V/RHEの雨位におい ても試料Eは他の試料より電流密度が高く，最も耐食性 が悪いと判断された。

高性能グレード炭秦䋐維の中 $(\mathrm{A} \sim \mathrm{D})$ の比較では，P

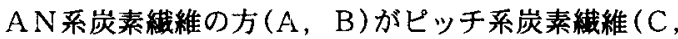
D)より電流值が低く，リン酸電解質に対しては不活性 であった。このピッチ系炭素織維はラジアル構造に起因 して比較的活性な黒鈶エッ涪が表面に現れ，リン酸電解 質に対し高い活性を示すと思われる，逆にPAN系炭素 緎維の内部はランダム棈造であるが, 織維の表面近傍は オニオン構造を有しこの不活性な表面によって電流密度 が低くなったと思われる．同じ系列の炭素織維で比較す ると, $0.9 \mathrm{~V} / \mathrm{RHE} ゙ は$ 照鈶化度の低い試料 A, Cの方が 電流密度が低かったが，この試料は電位の変化に対する 電流密度の上昇度合いが大きいため，1.1V/RHEでは黒銛 化度の高い試料より高い電流密度となった。1.1V/RHEの

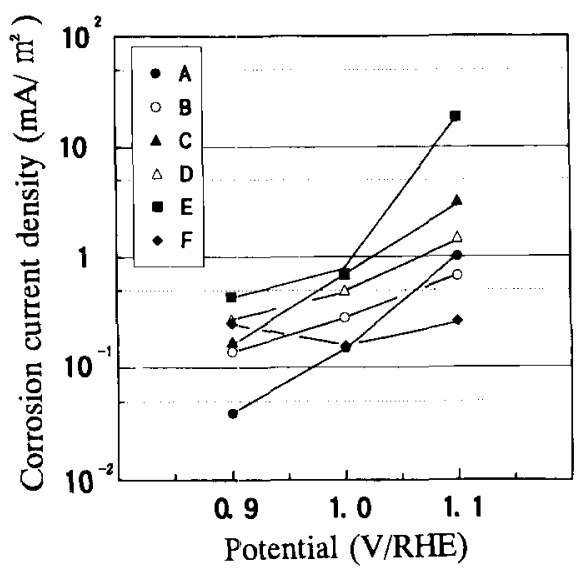

Fig.3 Corrosion currents after the test of $720 \mathrm{~min}$. at $0.9 \mathrm{~V} / \mathrm{RHE}, 1.0 \mathrm{~V} / \mathrm{RHE}, 1.1 \mathrm{~V} / \mathrm{RHE}$ respectively, in phosphoric acid at $200^{\circ} \mathrm{C}$ for carbon fiber samples. 
電位では腐食反応が顕著に進行するものと思われ，腐食 しやすい構造乱れの少なく黒鈶化度の高い試料が耐食性 が离く，電流密度が低かったと推察される：この結果か ら，異常運転や局所的に電位が亩い状態にある場合を想 定すると，黒鈶化度の高い方が耐食性が良い.

また, 試料 Fでは電位上昇に伴う電流の変化は著しく 小さく，他の炭素綞維とは異った挙動を示したここの輒 流の停漟現象は, 陽極酸化反応において酸化中間生成物 が保護膜となって電流(腐食) 抑制の働きをするものと推 察される.

3.2. 2 高電位長期腐食試験結果炭素瀻維の熱リン 酸中における陽極酸化は，一般に下式の反応で進むと言 われている。

$$
\mathrm{C}+2 \mathrm{H}_{2} \mathrm{O} \rightarrow \mathrm{CO}_{2}+4 \mathrm{H}^{+}+4 \mathrm{e}^{-}\left(\mathrm{E}_{0}=0.207 \mathrm{~V} / \mathrm{SHE}\right)
$$

定常運転に近い電位 $0.9 \mathrm{~V} / \mathrm{RHE}$ での電流值と上記腐食反 応から 4 万時間発電した時の消耘量を計算すると $3 \%$ 以 下となり，問題になるレベルではない，そこで異常運転 や局所的電位上昇など長期発電における信頼性, 寿命を 確認するために, 電位を $1.1 \mathrm{~V} / \mathrm{RHI}$, 温度を $210^{\circ} \mathrm{Cに上げ}$ た条件で長時間腐食試験 $(10,000$ 分)を行い, 試料の重量 減少 (Table 4), SEM観察による形状変化 (Fig. 4)を 調べた。黑鈶化度の高い試料 B，C，Dでは腐食に伴う 重量減少は微量で，特にB，Dは付着物によると思われ る微量の重量增加がみられた。これらの炭素㵶維は S E M観察でも腐食に伴う著しい㚆化は確認されなかった。

ほとんど黒鈶化されていない試料 $\mathrm{E} は$ 前記定電位腐食 試験の結果と同様に電流值が高く，腐食量も著しく大き く最も耐食性が悪かったＳＥM観察によりこの試料の 腐食の棣相をみると，全体的に表面が著しく荒れて所々 ピット状に侵食され，先端も丸くなっていた。

試料Aでは数\%の腐食重量減少があり，この腐食試験 後の電解液は試料 $\mathrm{E} の$ 時と同じく黒褐色を呈した。腐食 試験後の試料の状態を観察すると，表面が荒れ，クラッ

Table4 Weight loss after the test of $10,000 \mathrm{~min}$. and average of current density for $10,000 \mathrm{~min}$. at $1.1 \mathrm{~V} / \mathrm{RHE}$ in phosphoric acid at $210^{\circ} \mathrm{C}$ for carbon fibers.

\begin{tabular}{ccc}
\hline Sample & $\begin{array}{c}\text { Weight loss } \\
(\%)\end{array}$ & $\begin{array}{c}\text { Current density } \\
\left(\mathrm{mA} / \mathrm{m}^{2}\right)\end{array}$ \\
\hline A & 4.5 & 3.9 \\
B & $\boldsymbol{\Delta} 0.5$ & 0.4 \\
C & 0.2 & 2.0 \\
D & $\mathbf{\Delta} 0.02$ & 1.0 \\
E & 32.4 & 700 \\
F & 1.5 & 4.5 \\
\hline
\end{tabular}

クが入り，さらにクラックの内部が侵食されている様子 が窥える．また先端部分は表面の一皮を残して空洞が生 じていること，中央部に芯が残っている形状変化が観察 された。このことからも，PAN系炭素織維の表層部は コア部より腐食を受け難く耐食性が碀い構造(オニオン スキン構造)を有しているごとが判った。

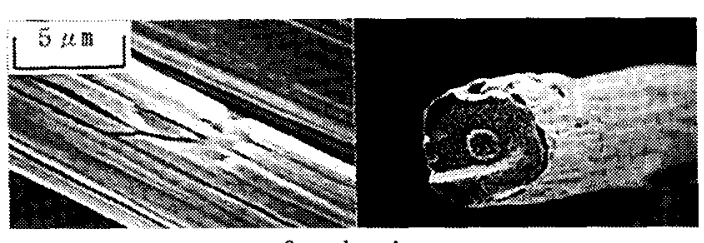

Sample A

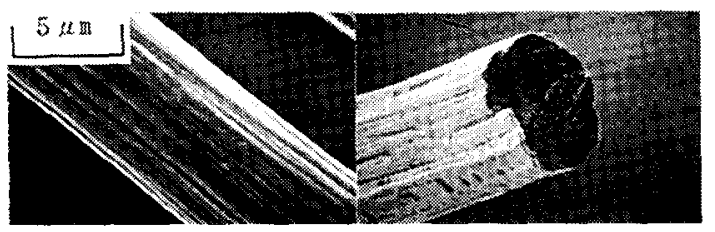

Sample B

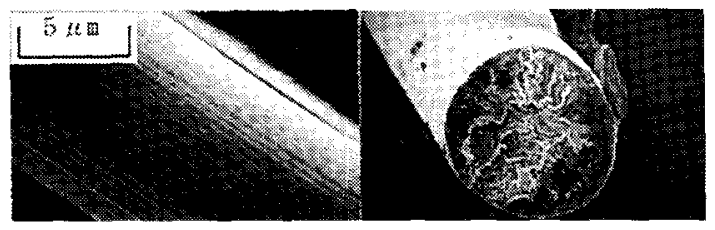

Sample C

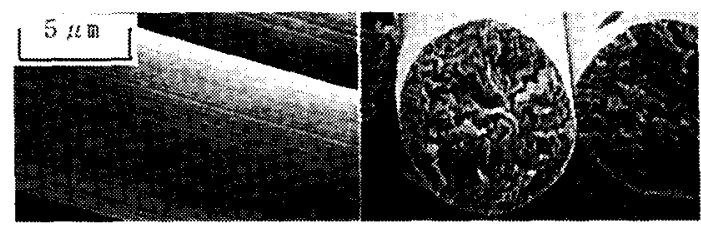

Sample D

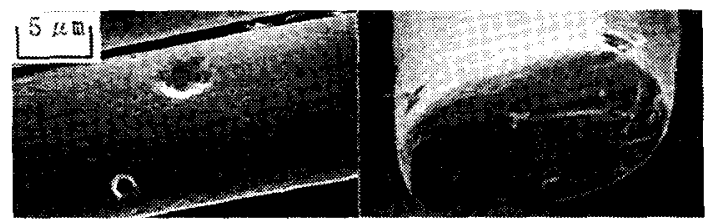

Sample E

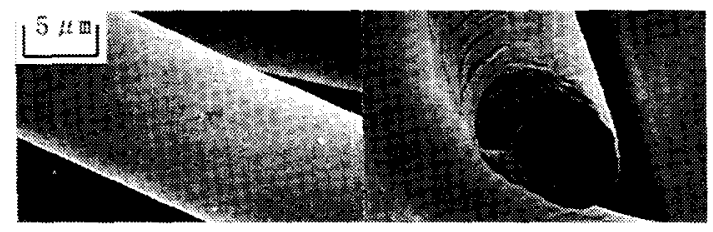

Sample F

Fig.4 SEM photographs of carbon fibers after corrosion test for $10,000 \mathrm{~min}$. at $1.1 \mathrm{~V} / \mathrm{RHE}$ in phosphoric acid at $210^{\circ} \mathrm{C}$. 


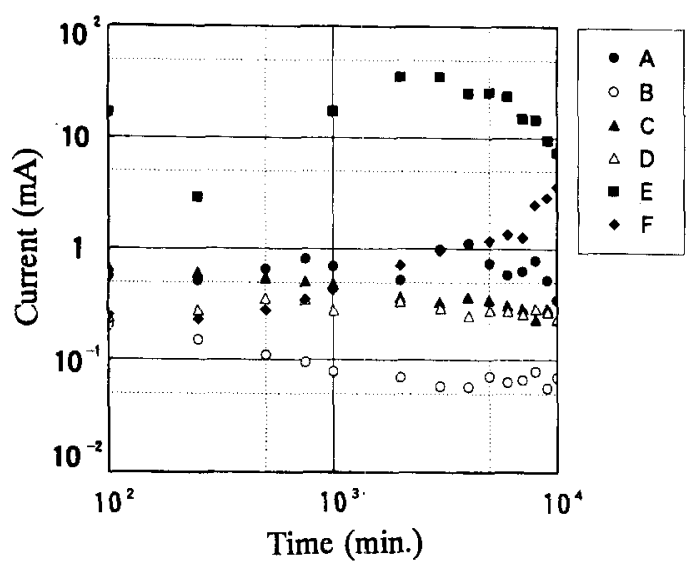

Fig. 5 Corrosion currents as a function of time for carbon fiber samples at 1.1V/RHE in phosphoric acid at $210^{\circ} \mathrm{C}$.

Fig. 5 に長時間腐食試験における電流実測値の変化を 示した. 耐食性の悪かった試料Eは200分過ぎから腐食 に伴う表面積の增大などから電流の上昇が見られた。さ らに，定電位腐食試験の高電位側で電流密度の小さかっ

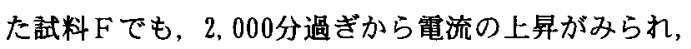
腐食試铪での平均電流密度代試料 A と同程度となった。 腐食に伴う重量減少が $1.5 \%$ となり，他の試料 B，C， Dと比較して，試料 F は酎食性が良くない，腐食前は滑 らかな表面であったこの試料の腐食試験後の表面には， 所々傷のような腐食を受けた痕跡が認められた。

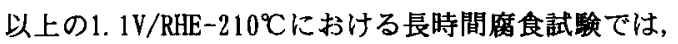
腐食に伴亏重量娍少, 電流密度, 形状変化の結果から, 最も耐食性の良い炭秦瀻維としてPAN系炭素織維の高 弾性率品が挙げられる。これは黒銛化度が高く且つオ二 オンスキン構造の表面を持つため高耐食性を示したもの と考えられる。

\section{4 まとめ}

6 種の炭素襶維を選定し，それらの基本的特性を測定 し, 実用的特性である耐食性との関係について比較した 結果，以下の結論が得られた。
(1) 弾性率が高い炭素織維ほよ゙黒鈶化度は高く，腐食が 顕著となる高電位条件下で耐食性（腐食電流, 鹰食 量）を比較すると，黑鈶化度の高い炭素織維ほど耐 食性が良好であることが判明した。

（2）熱リン酸中での陽橝酸化に対して，オニオンスキン 構造を有するPAN系炭素繊維の高弾性率品が最も 不活性であった。

（3）ガラス状炭素質の炭素織維では，炭素の陽極酸化中 間生成物によると推祭される電位に対する電流上昇 が小さく特異な挙動を示した。

（4）本実験に用いた試料は，アルゴンガス中， $1050{ }^{\circ} \mathrm{C} の$ 熱好理を行ったため, 表面酸素量は著しく少なく, 耐食性に影粟を及ぼすほどではなかった。

(5)試料Aの窒素分の影響は明らかではないが，腐食電 流，腐食量と不純物量 (死分) の関連性を見ると，数 十ppmレベルの灰分量ではさほど耐食性に影制しな いと思われる.

燃料電池での実用的特性には炭素瀻維の黒鉿化度が大 きく関与していることが窥われたので, 今後は熱処理に よる黒鎮化度の変化をパラメータとして，基本的特性の 変化を知り，さらに実用的特性との関係を明らかにする 必要がある．またバインダーと骨格となる炭素織維の相 互作用, 複合材料としての構造を調べ, P A F C 電極基 に適したカーボン材料の性状を明らかにする。

\section{文献}

1)K.Kinoshita, CARBON, electrochemical and physicochemical properties, John Wiley and Sons, New York, p.316(1987).

2)A.J.Appleby, Corrosion 86, paper no.79 (1986).

3)J.P.Macdonald and P.Stonehart, Corrosion 86, paper no.81 (1987).

4)P.L.Antonucci and G.Pinna, Materials Chemistry and Physics, 21, 495(1989).

5) 松井醇一, 炭素紻維の展開之評価方法, 炭素材料学 編，リアライズ社，(1989).

6) 大谷杉郎, 奧田謙介, 松田 滋, 炭素緎維, 增補改訂, 近代編集社，p.204(1986).

7)A.Tomita, et al., Carbon 21, 225 (1983). 